\title{
Novel Keeling-plot-based methods to estimate the isotopic composition of ambient water vapor
}

\author{
Yusen Yuan ${ }^{1,2}$, Taisheng Du ${ }^{1}$, Honglang Wang ${ }^{3}$, and Lixin Wang ${ }^{2}$ \\ ${ }^{1}$ Center for Agricultural Water Research in China, China Agricultural University, Beijing 100083, China \\ ${ }^{2}$ Department of Earth Sciences, Indiana University-Purdue University Indianapolis, Indianapolis, Indiana 46202, USA \\ ${ }^{3}$ Department of Mathematical Sciences, Indiana University-Purdue University Indianapolis, \\ Indianapolis, Indiana 46202, USA
}

Correspondence: Lixin Wang (wang.iupui@gmail.com) and Taisheng Du (dutaisheng@cau.edu.cn)

Received: 2 January 2020 - Discussion started: 16 January 2020

Revised: 5 July 2020 - Accepted: 29 July 2020 - Published: 16 September 2020

\begin{abstract}
The Keeling plot approach, a general method to identify the isotopic composition of source atmospheric $\mathrm{CO}_{2}$ and water vapor (i.e., evapotranspiration), has been widely used in terrestrial ecosystems. The isotopic composition of ambient water vapor $\left(\delta_{\mathrm{a}}\right)$, an important source of atmospheric water vapor, is not able to be estimated to date using the Keeling plot approach. Here we proposed two new methods to estimate $\delta_{\mathrm{a}}$ using the Keeling plots: one using an intersection point method and another relying on the intermediate value theorem. As the actual $\delta_{\mathrm{a}}$ value was difficult to measure directly, we used two indirect approaches to validate our new methods. First, we performed external vapor tracking using the Hybrid Single Particle Lagrangian Integrated Trajectory (HYSPLIT) model to facilitate explaining the variations of $\delta_{\mathrm{a}}$. The trajectory vapor origin results were consistent with the expectations of the $\delta_{\mathrm{a}}$ values estimated by these two methods. Second, regression analysis was used to evaluate the relationship between $\delta_{\mathrm{a}}$ values estimated from these two independent methods, and they are in strong agreement. This study provides an analytical framework to estimate $\delta_{\mathrm{a}}$ using existing facilities and provides important insights into the traditional Keeling plot approach by showing (a) a possibility to calculate the proportion of evapotranspiration fluxes to total atmospheric vapor using the same instrumental setup for the traditional Keeling plot investigations and (b) perspectives on the estimation of isotope composition of ambient $\mathrm{CO}_{2}$ $\left(\delta_{\mathrm{a}}{ }^{13} \mathrm{C}\right)$.
\end{abstract}

\section{Introduction}

Stable isotopes of hydrogen and oxygen $\left({ }^{1} \mathrm{H}^{2} \mathrm{HO}\right.$ and $\left.\mathrm{H}_{2}^{18} \mathrm{O}\right)$ have been widely used in root water uptake source identification (Corneo et al., 2018; Mahindawansha et al., 2018; Lanning et al., 2020) and evapotranspiration (ET) partitioning (Brunel et al., 1997; Wang et al., 2010; Cui et al., 2020) in terrestrial ecosystems based on the Craig-Gordon model (Craig and Gordon, 1965), isotope mass balance and mechanisms of isotopic fractionation (Majoube, 1971; Merlivat and Jouzel, 1979). With the advent of laser isotope spectrometry capable of high-frequency $(1 \mathrm{~Hz})$ measurements of the isotopic composition of atmospheric water vapor $\left(\delta_{\mathrm{v}}\right)$ and atmospheric water vapor content $\left(C_{\mathrm{v}}\right)$ (Kerstel and Gianfrani, 2008; Wang et al., 2009), the number of studies based on high-frequency ground-level isotope measurements was continuously increasing. These studies generate new insights into the processes that affect $\delta_{\mathrm{V}}$, including meteorological factors (Galewsky et al., 2011; Steen-Larsen et al., 2013), biotic factors (Wang et al., 2010) and multiple factors (Parkes et al., 2016). Such an increase in $\delta_{\mathrm{v}}$ measurements allows isotope-enabled global circulation models (Iso-GCMs) to estimate the variation of water vapor isotope parameters at a global scale (Werner et al., 2011). Concomitantly, more than $\delta_{\mathrm{V}}$, several new methods using high-frequency ground-level isotope measurements were devised to directly estimate the isotopic composition of leaf water (Song et al., 2015) and leaf-transpired vapor (Wang et al., 2012).

Evapotranspiration is a crucial component of the water budget across scales such as the field (Wagle et al., 2020), 
watershed (Zhang et al., 2001), regional (Hobbins et al., 2001) and global (Jung et al., 2010, Wang et al., 2014) scales. The water isotopic composition of ET $\left(\delta_{\mathrm{ET}}\right)$ was generally estimated by the Keeling plot approach (Keeling, 1958). It was first used to explain carbon isotope ratios of atmospheric $\mathrm{CO}_{2}$ and to identify the sources that contribute to increases in atmospheric $\mathrm{CO}_{2}$ concentration, and it has been further used to estimate $\delta_{\mathrm{ET}}$ in the past 2 decades (Yakir and Sternberg, 2000). The Keeling plot analyses can be applied using $\delta_{\mathrm{V}}$ and $C_{\mathrm{v}}$ output by a laser-based analyzer either from different heights (Yepez et al., 2003; Zhang et al., 2011; Good et al., 2012) or at one height with continuous observations (Wei et al., 2015; Keppler et al., 2016). Although the intercept of the linear-regression line was commonly used as estimated $\delta_{\mathrm{ET}}$, the slope of the Keeling plot was also used to estimate $\delta_{\mathrm{ET}}$ by re-arranging the Keeling plot equations (Miller and Tans, 2003; Fiorella et al., 2018). The Keeling plot approach was based on isotope mass balance and a two-source assumption using two equations with three unknowns. As a result, the isotopic composition of other potential sources (e.g., water vapor not from ET), as well as the isotopic composition of ambient water vapor $\left(\delta_{\mathrm{a}}\right)$, were not able to be estimated directly using the Keeling plot approach. That is one of the reasons why field scale moisture recycling has been difficult to estimate to date.

In this study, we proposed two new methods to estimate $\delta_{\mathrm{a}}$, one based on the intersection of two Keeling plots of two continuous observation moments and the other based on the intermediate value theorem. Proposition and proof were provided, and the new methods were tested using field observations. As direct observations of $\delta_{\mathrm{a}}$ rarely exist (Griffis et al., 2016), we tested our methods by (a) performing an investigation of external water vapor tracking according to the Hybrid Single Particle Lagrangian Integrated Trajectory (HYSPLIT) model to explain the variations of estimated $\delta_{\mathrm{a}}$ and (b) making a regression analysis on a daily scale and point-to-point scale using $\delta_{\mathrm{a}}$ estimated by these two independent methods.

\section{Materials and methods}

\subsection{Theory}

The atmospheric vapor concentration in an ecosystem reflects the combination of ambient vapor that already exists in the atmosphere and the vapor that is added through evaporation $(E)$ and transpiration $(T)$ (Yakir and Sternberg, 2000). The Keeling plot approach is based on the combination of a bulk water mass balance equation and an isotope mass balance equation:

$C_{\mathrm{v}}=C_{\mathrm{a}}+C_{\mathrm{ET}}$,

$C_{\mathrm{v}} \delta_{\mathrm{v}}=C_{\mathrm{a}} \delta_{\mathrm{a}}+C_{\mathrm{ET}} \delta_{\mathrm{ET}}$,

where $\delta_{\mathrm{a}}, \delta_{\mathrm{ET}}$ and $\delta_{\mathrm{v}}$ are the isotope composition of ambient water vapor, ET and atmospheric water vapor, respectively, and $C_{\mathrm{a}}, C_{\mathrm{ET}}$ and $C_{\mathrm{v}}$ are the corresponding concentrations of water vapor. Note that all quantities here are time dependent, and $\delta_{\mathrm{v}}$ and $C_{\mathrm{v}}$ also depend on heights.

Combining Eqs. (1) and (2), we have the following traditional linear Keeling plot relationship between $\delta_{\mathrm{v}}$ and $1 / C_{\mathrm{v}}$ with intercept $\delta_{\mathrm{ET}}$ and slope $C_{\mathrm{a}}\left(\delta_{\mathrm{a}}-\delta_{\mathrm{ET}}\right)$,

$\delta_{\mathrm{v}}=C_{\mathrm{a}}\left(\delta_{\mathrm{a}}-\delta_{\mathrm{ET}}\right) / C_{\mathrm{v}}+\delta_{\mathrm{ET}}$.

For a given time, with various measurements of $\delta_{\mathrm{v}}$ and $C_{\mathrm{v}}$ collected at different heights, we are able to estimate the intercept $\delta_{\mathrm{ET}}$ and slope $k=C_{\mathrm{a}}\left(\delta_{\mathrm{a}}-\delta_{\mathrm{ET}}\right)$ for this moment from regression analysis (Zhang et al., 2011; Wang et al., 2013). Here we focus on the estimation of $\delta_{\mathrm{a}}$ using two new methods proposed below.

Intersection point (IP) method. Note that for two nearby time points $t_{1}$ and $t_{2}$, we could use local-constant approximation to estimate $\delta_{\mathrm{a}}$ within this time interval, since it remains relatively constant over a short period of time. By assuming a local constant for $C_{\mathrm{a}}$ and $\delta_{\mathrm{a}}$ within this time interval, we have

$k_{1}=C_{\mathrm{a}}\left(\delta_{\mathrm{a}}-\delta_{\mathrm{ET}_{1}}\right)$,

$k_{2}=C_{\mathrm{a}}\left(\delta_{\mathrm{a}}-\delta_{\mathrm{ET}_{2}}\right)$,

where $k_{i}$ and $\delta_{\mathrm{ET}_{i}}$ represent the value at $t_{i}$ for $i=1,2$. From Eqs. (4) and (5), we can solve $\delta_{\mathrm{a}}$ as

$\delta_{\mathrm{a}}=\frac{k_{1} \delta_{\mathrm{ET}_{2}}-k_{2} \delta_{\mathrm{ET}_{1}}}{k_{1}-k_{2}}$.

Algebraically, $\delta_{\mathrm{a}}$ and $C_{\mathrm{a}}$ are solutions in Eqs. (4) and (5). Geometrically, point $\left(\delta_{\mathrm{a}}, 1 / C_{\mathrm{a}}\right)$ is the intersection of two Keeling plots at $t_{1}$ and $t_{2}$. That is the reason the method was named the IP method. The local-constant approximation idea was first described in Yamanaka and Shimizu (2007) as an assumption to quantify the contribution of local ET to total atmospheric vapor.

Intermediate value theorem (IVT) method. Denote the slope as $k=C_{\mathrm{a}}\left(\delta_{\mathrm{a}}-\delta_{\mathrm{ET}}\right)$. As $C_{\mathrm{a}}<C_{\mathrm{v}}=C_{\mathrm{a}}+C_{\mathrm{ET}}$, we have $C_{\mathrm{a}}=\frac{k}{\left(\delta_{\mathrm{a}}-\delta_{\mathrm{ET}}\right)}<C_{\mathrm{v}}$. We can rearrange $\frac{k}{\left(\delta_{\mathrm{a}}-\delta_{\mathrm{ET}}\right)}<C_{\mathrm{v}}$ to attain $\delta_{\mathrm{a}}: \delta_{\mathrm{a}}<\frac{k}{C_{\mathrm{v}}}+\delta_{\mathrm{ET}}=\delta_{\mathrm{v}}$ when $k<0$ and $\delta_{\mathrm{a}}>\frac{k}{C_{\mathrm{v}}}+\delta_{\mathrm{ET}}=\delta_{\mathrm{v}}$ when $k>0$.

For the smooth function $\delta_{\mathrm{a}}(t)$ defined on the interval $\left[t_{1}, t_{2}\right]$ with the two time points satisfying $k\left(t_{1}\right) k\left(t_{2}\right)<0$, depending on the sign of the slopes $k\left(t_{1}\right)$ and $k\left(t_{2}\right)$ and the order of $\delta_{\mathrm{v}_{1}}=\delta_{\mathrm{v}}\left(t_{1}\right)$ and $\delta_{\mathrm{v}_{2}}=\delta_{\mathrm{v}}\left(t_{2}\right)$ at the two time points $t_{1}$ and $t_{2}$, it will correspond to one of the situations in Fig. 1. For all of the situations, following the intermediate value theorem, there exists a subinterval $\left[t_{1}^{\prime}, t_{2}^{\prime}\right] \subset\left[t_{1} t_{2}\right]$ such that the whole range of $\left\{\delta_{\mathrm{a}}(t): t \in\left[t_{1}^{\prime}, t_{2}^{\prime}\right]\right\}$ is within $\left[\min \left(\delta_{\mathrm{v}_{1}} \delta_{\mathrm{V}_{2}}\right), \max \left(\delta_{\mathrm{v}_{1}} \delta_{\mathrm{V}_{2}}\right)\right]$. Proof details of this proposition are shown in the Supplement. Thus for the two nearby time points $t_{1}$ and $t_{2}$ with $k_{1}$ and $k_{2}$ having different signs, $\delta_{\mathrm{a}}$ will be between $\delta_{\mathrm{v}_{1}}$ and $\delta_{\mathrm{V}_{2}}$. This provides a prerequisite for estimating the parameter of interest $\delta_{\mathrm{a}}$ based on the intermediate 


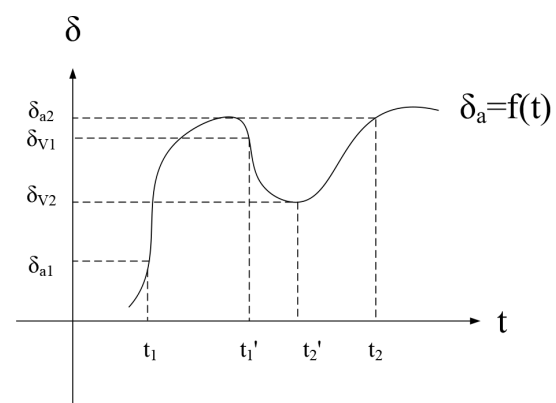

(a)

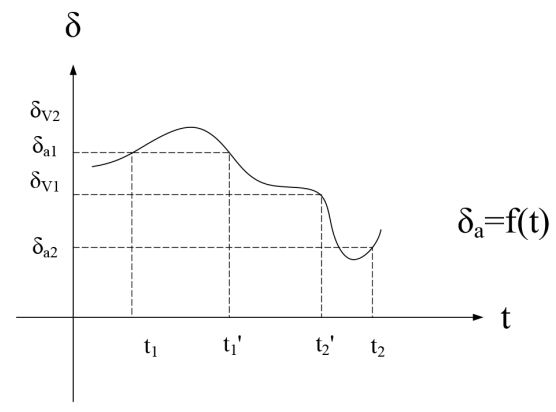

(c)

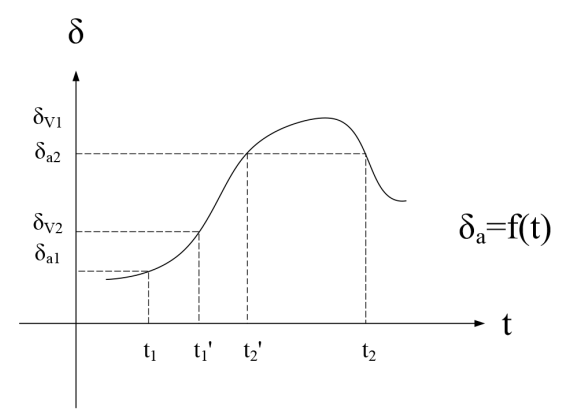

(e)

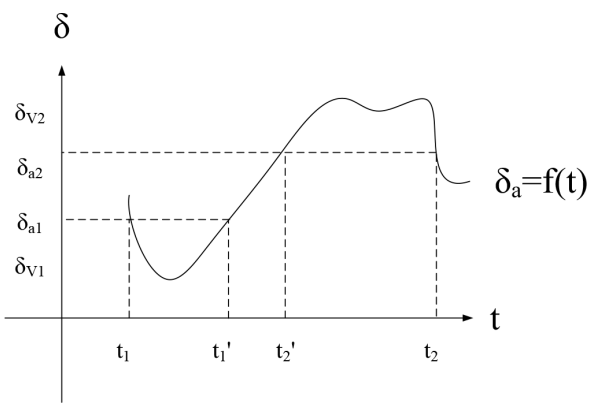

(b)

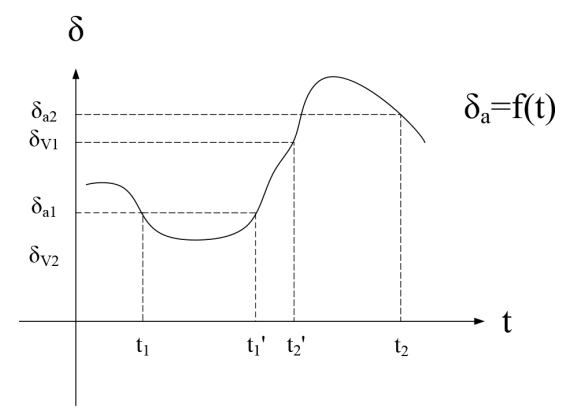

(d)

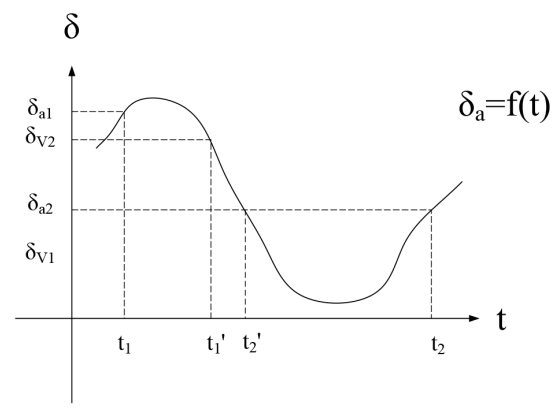

(f)

Figure 1. Theoretical diagrams of all possible combinations of the relationships between isotope composition of ambient vapor $\left(\delta_{\mathrm{a}}\right)$ and the observed isotope composition of atmospheric vapor $\left(\delta_{\mathrm{V}}\right)$ of two continuous moments $t_{1}$ and $t_{2},\left(t_{1}<t_{2}\right)$. $\delta_{\mathrm{a} 1}$ and $\delta_{\mathrm{a} 2}$ represent the $\delta_{\mathrm{a}}$ value in $t_{1}$ and $t_{2}$, respectively. $\delta_{\mathrm{v} 1}$ and $\delta_{\mathrm{v} 2}$ represent the $\delta_{\mathrm{V}}$ value in $t_{1}$ and $t_{2}$, respectively. $t_{1}^{\prime}$ and $t_{2}^{\prime}$ represent the time of two specific moments between $t_{1}$ and $t_{2}$ with $t_{1}<t_{1}^{\prime}<t_{2}^{\prime}<t_{2}$. For all of the six situations, there are some subintervals $\left[t_{1}^{\prime}, t_{2}^{\prime}\right] \subset\left[t_{1} t_{2}\right]$ such that the whole range of $\delta_{\mathrm{a}}(t): t \in\left[t_{1}^{\prime}, t_{2}^{\prime}\right]$ is within $\left[\min \left(\delta_{\mathrm{v}_{1}} \delta_{\mathrm{V}_{2}}\right), \max \left(\delta_{\mathrm{v}_{1}} \delta_{\mathrm{V}_{2}}\right)\right]$.

value theorem, which leads to an approximation of $\delta_{\mathrm{a}}$ within the time interval between $t_{1}$ and $t_{2}$ using $\delta_{\mathrm{v}_{1}}$ and $\delta_{\mathrm{v}_{2}}$ :

$\delta_{\mathrm{a}} \approx \frac{\delta_{\mathrm{v}_{1}}+\delta_{\mathrm{v}_{2}}}{2}$

Using this method, we are able to compute $\delta_{\mathrm{a}}$ using data points when the slopes of Keeling plots change signs between two adjacent time points.

\subsection{Field observations}

\subsubsection{Study site}

A field measurement was conducted over a maize field (39 ha) from 1 May 2017 to 30 September 2017 at the Shiyanghe Experimental Station of China Agricultural University, located in Wuwei of Gansu province, northwestern China $\left(37^{\circ} 85^{\prime} \mathrm{N}, 102^{\circ} 88^{\prime} \mathrm{E}\right.$; altitude $\left.1581 \mathrm{~m}\right)$. The region belongs to a temperate continental climate and is in the oa- 
sis within the Shiyang River basin. The annual mean temperature of the study area is about $8.8^{\circ}$ with pan evaporation of $2000 \mathrm{~mm}$, annual precipitation of $164.4 \mathrm{~mm}$, mean sunshine duration of $3000 \mathrm{~h}$ and frost-free period of more than $150 \mathrm{~d}$. The local crops are irrigated using groundwater with electrical conductivity of $0.62 \mathrm{dS} \mathrm{m}^{-1}$. The groundwater table is $30-40 \mathrm{~m}$ below the surface. Maize was sowed in April and harvested in September 2017, with a row spacing of $40 \mathrm{~cm}$ and plant spacing of $23 \mathrm{~cm}$. The maize growing stage was divided into the seedling stage (21 April20 May), jointing stage (21 May-10 July), heading period (11-31 July), pustulation period (1-31 August) and mature period (1-20 September).

\subsubsection{Instrumental setup and measurement design}

A $24 \mathrm{~m}$ flux tower, located in the middle of the maize field, was used to measure the ET flux and isotopic composition of water vapor at different heights. The field is approximately $600 \mathrm{~m}$ long and $240 \mathrm{~m}$ wide, with a $1 \%$ slope decreasing from southwest to northeast. Five gas traps were installed on the flux tower at heights of $4,8,12,16$ and $20 \mathrm{~m}$, respectively. An iron pillar was placed $20 \mathrm{~m}$ away from the flux tower. Three gas traps were installed on the iron pillar; one was close to the canopy, and the other two were 2 and $3 \mathrm{~m}$ above the ground. The gas trap by the canopy was adjusted weekly according to the height of maize.

In situ $\delta_{\mathrm{v}}$ and $C_{\mathrm{v}}$ collected by the eight gas traps were monitored by a water vapor isotope analyzer (L2130-i, Picarro Inc., Sunnyvale, CA, USA), which was a wavelengthscanned cavity ring-down spectroscope (WS-CRDS) instrument. Vapor specifications include a measurement range from 1000 to $50000 \mathrm{ppm}$; the precision is $0.04 \%$ o to $0.25 \%$ o for $\delta^{18} \mathrm{O}$ (Zhao et al., 2019). Interfacing with the gas trap and the isotope analyzer, a teflon tube was wrapped by thermal insulation cotton to avoid vapor condensation during transmission. The measurement of $\delta_{\mathrm{v}}$ and $C_{\mathrm{v}}$ was conducted from May to September, which should have $153 \mathrm{~d}$ of data; $49 \mathrm{~d}$ among them were complete with $24 \mathrm{~h}$ continuous datasets. There were missing data for either a whole day or several hours of a day for other days due to the calibration and maintenance of the analyzer. These $49 \mathrm{~d}$ were chosen in our study for data analysis.

\subsubsection{Calibration of $\delta_{\mathrm{v}}$ and $C_{\mathrm{v}}$}

Our calibration procedure mainly followed the study by Steen-Larsen et al. (2013) with some modifications to fit our specific experimental setup. The water vapor from eight inlets was sampled continuously over a $24 \mathrm{~h}$ period. Since only one analyzer was used to measure $\delta_{\mathrm{v}}$ and $C_{\mathrm{v}}$, the values of eight sampling inlets were recorded in turn every $225 \mathrm{~s}$ in a $30 \mathrm{~min}$ cycle. The switch procedure was automatic. As the analyzer makes a measurement every $0.9-1 \mathrm{~s}$, approximately 259-264 values for each inlet was recorded within the cycle.
For each $225 \mathrm{~s}$ measurement period, data points 195 to 253 were used to avoid a memory issue and the influence of transient pressure variation. The absolute value of the coefficient of variation $(|\mathrm{CV}|)$ of $\delta_{\mathrm{v}}$ and $C_{\mathrm{v}}$ was no more than 0.016 and 0.002 , respectively, which was far below the critical value of $15 \%$ (Lovie, 2005). The mean value of the selected data points was regarded as the measured $\delta_{\mathrm{v}}$ and $C_{\mathrm{v}}$ in a specific inlet. Measured $C_{\mathrm{v}}$ was used directly as actual $C_{\mathrm{v}}$, while measured $\delta_{\mathrm{v}}$ was calibrated to minimize the influence of isotopic-concentration dependence. The $C_{\mathrm{v}}$ in our measurement ranged from 5386 to $30255 \mathrm{ppm}$. Thus, $C_{\mathrm{v}}$ gradients of 10000,20000 and $30000 \mathrm{ppm}$ were selected as calibration concentrations to improve the precision of $\delta_{\mathrm{v}}$. As we need continuous data, the observation should last uninterrupted as long as possible. As a result, the calibration was made every 5-10 d, which is consistent with the frequency of calibration by other researchers such as Steen-Larsen et al. (2013). According to our calibration data on standards, the average drift (absolute value) was about $0.16 \%$ between two adjacent calibrations.

\subsection{Data quality control for $\delta_{\mathrm{a}}$ estimation}

With a 30 min interval for $49 \mathrm{~d}$, we should in theory produce $2352 \delta_{\mathrm{a}}$ values for both the IP method and IVT method. However, because of the precondition of $k_{1} k_{2}<0$ required for the IVT method, $166 \delta_{\mathrm{a}}$ values were able to be calculated using the IVT method $\left(\delta_{\mathrm{a}(\mathrm{IVT})}\right)$. $\delta_{\mathrm{a}}$ values using the IP method $\left(\delta_{\mathrm{a}(\mathrm{IP})}\right)$ were not restricted by this precondition. Furthermore, a filter $\left(\delta_{\mathrm{ET}}<\delta_{\mathrm{v}}<\delta_{\mathrm{a}}\right.$ or $\left.\delta_{\mathrm{ET}}>\delta_{\mathrm{v}}>\delta_{\mathrm{a}}\right)$ was used for both methods because $\delta_{\mathrm{v}}$ was a mixture of $\delta_{\mathrm{ET}}$ and $\delta_{\mathrm{a}}$. Therefore, $\delta_{\mathrm{a}}$ values that meet both precondition $k_{1} k_{2}<0$ and the condition of $\delta_{\mathrm{ET}}<\delta_{\mathrm{v}}<\delta_{\mathrm{a}}$ or $\delta_{\mathrm{ET}}>\delta_{\mathrm{v}}>\delta_{\mathrm{a}}$ were considered to satisfy the criteria for the IVT method; $\delta_{\mathrm{a}}$ values that meet the condition of $\delta_{\mathrm{ET}}<\delta_{\mathrm{v}}<\delta_{\mathrm{a}}$ or $\delta_{\mathrm{ET}}>\delta_{\mathrm{v}}>\delta_{\mathrm{a}}$ were considered to satisfy the criteria for the IP method. In the end, we obtained 1264 and $103 \delta_{\mathrm{a}}$ values using IP and IVT methods, respectively (Table 1). A total of 88 time points were overlapped between the IP- and IVT-based $\delta_{\mathrm{a}}$ results. These 88 time points were selected to test the reliability of two methods at a point-to-point scale. During the $49 \mathrm{~d}$, there were $21 \mathrm{~d}$ when more than one $\delta_{\mathrm{a}(\mathrm{IVT})}$ was attained for each day. These $21 \mathrm{~d}$ was also used to investigate the time series of daily-scale $\delta_{\mathrm{a}}$ variations and other isotopic variations. Further analysis in Sect. 2.4 of the following was made on these $21 \mathrm{~d}$.

\subsection{Explanations of $\delta_{\mathrm{a}}$ using backward trajectories}

To explain the variations of estimated $\delta_{\mathrm{a}}$, air mass backward trajectories were calculated using the Hybrid Single Particle Lagrangian Integrated Trajectory (HYSPLIT) model (Draxler and Hess, 1997; Draxler, 2003; Stein et al., 2015; Kaseke et al., 2018) and meteorological data from the Global Data Assimilation System $0.5^{\circ}$ (GDAS0p5) dataset with $0.5^{\circ} \times 0.5^{\circ}$ spatial resolution and $3 \mathrm{~h}$ time resolution for the 
Table 1. The number of the estimated isotope composition of ambient vapor meeting the criteria using the intersection point method $\left(\delta_{\mathrm{a}(\mathrm{IP})}\right)$ and the intermediate value theorem method $\left(\delta_{\mathrm{a}(\mathrm{IVT})}\right)$ among all $49 \mathrm{~d}$.

\begin{tabular}{|c|c|c|}
\hline Date & $\begin{array}{r}\text { Number of acceptable } \\
\delta_{\mathrm{a}(\mathrm{IP})} \text { values } \\
\text { in a whole day }\end{array}$ & $\begin{array}{r}\text { Number of acceptable } \\
\delta_{\mathrm{a}(\mathrm{IVT})} \text { values } \\
\text { in a whole day }\end{array}$ \\
\hline 19 May & 27 & 8 \\
\hline 27 May & 13 & 3 \\
\hline 28 May & 30 & 3 \\
\hline 31 May & 25 & 5 \\
\hline 4 Jun & 38 & 5 \\
\hline 5 Jun & 28 & 0 \\
\hline 7 Jun & 29 & 6 \\
\hline 9 Jun & 32 & 5 \\
\hline 10 Jun & 26 & 2 \\
\hline 11 Jun & 21 & 4 \\
\hline 12 Jun & 22 & 4 \\
\hline 15 Jun & 32 & 0 \\
\hline 16 Jun & 33 & 0 \\
\hline 17 Jun & 24 & 1 \\
\hline 18 Jun & 26 & 0 \\
\hline 21 Jun & 26 & 3 \\
\hline 22 Jun & 22 & 0 \\
\hline 26 Jun & 22 & 0 \\
\hline 27 Jun & 29 & 3 \\
\hline $4 \mathrm{Jul}$ & 23 & 0 \\
\hline $5 \mathrm{Jul}$ & 23 & 1 \\
\hline $7 \mathrm{Jul}$ & 30 & 0 \\
\hline $8 \mathrm{Jul}$ & 29 & 0 \\
\hline $14 \mathrm{Jul}$ & 28 & 4 \\
\hline $16 \mathrm{Jul}$ & 28 & 0 \\
\hline $18 \mathrm{Jul}$ & 25 & 1 \\
\hline $19 \mathrm{Jul}$ & 28 & 6 \\
\hline $20 \mathrm{Jul}$ & 27 & 6 \\
\hline $21 \mathrm{Jul}$ & 29 & 0 \\
\hline $22 \mathrm{Jul}$ & 19 & 0 \\
\hline $3 \mathrm{Aug}$ & 18 & 1 \\
\hline $4 \mathrm{Aug}$ & 22 & 3 \\
\hline $5 \mathrm{Aug}$ & 25 & 3 \\
\hline 6 Aug & 28 & 1 \\
\hline 12 Aug & 13 & 8 \\
\hline 18 Aug & 19 & 3 \\
\hline 19 Aug & 30 & 0 \\
\hline 28 Aug & 23 & 0 \\
\hline $29 \mathrm{Aug}$ & 22 & 1 \\
\hline 30 Aug & 27 & 1 \\
\hline 31 Aug & 27 & 0 \\
\hline $20 \mathrm{Sep}$ & 25 & 0 \\
\hline $21 \mathrm{Sep}$ & 24 & 1 \\
\hline 22 Sep & 31 & 1 \\
\hline $23 \mathrm{Sep}$ & 28 & 1 \\
\hline 27 Sep & 28 & 2 \\
\hline $28 \mathrm{Sep}$ & 25 & 1 \\
\hline 29 Sep & 30 & 5 \\
\hline $30 \mathrm{Sep}$ & 25 & 1 \\
\hline
\end{tabular}

$21 \mathrm{~d}$ mentioned in Sect. 2.3. A height of $500 \mathrm{~m}$ was selected in the modeling. Each backward trajectory was initialized from the station $\left(37^{\circ} 85^{\prime} \mathrm{N}, 102^{\circ} 88^{\prime} \mathrm{E}\right)$ at $12: 00$ (LT) and calculated backward for $72 \mathrm{~h} ; 18$ trajectories were computed, excluding 21 June, 18 August and 29 September, when vertical velocity data were missing. Finally, we used these 18 trajectories representing the vapor origin in the corresponding $18 \mathrm{~d}$.

\section{Results}

\subsection{Time series variations of $\delta_{\mathrm{ET}}, \delta_{\mathrm{v}}, \delta_{\mathrm{a}}$ and $k$}

Time series of isotopic variations were shown in Fig. 2. The $\delta_{\mathrm{v}}$ here is the average value of eight heights. The average $\delta_{\mathrm{ET}}$, $\delta_{\mathrm{v}}, \delta_{\mathrm{a}(\mathrm{IP})}$ and $\delta_{\mathrm{a}(\mathrm{IVT})}$ were $-11.04 \%,-13.00 \%,-13.60 \%$ o and $-13.29 \%$, respectively, in those $21 \mathrm{~d}$ when more than one $\delta_{\mathrm{a}(\mathrm{IVT})}$ was attained for each day. Daytime-average $(07: 00-19: 00) \delta_{\mathrm{ET}}, \delta_{\mathrm{v}}, \delta_{\mathrm{a}(\mathrm{IP})}$ and $\delta_{\mathrm{a}(\mathrm{IVT})}$ were $-10.73 \%$, $-13.33 \%$ o $-14.08 \%$ and $-13.63 \%$, respectively. While at nighttime (19:00 to 07:00 the next day), average $\delta_{\mathrm{ET}}$ was lower than that at daytime, which was contrary to $\delta_{\mathrm{v}}, \delta_{\mathrm{a}(\mathrm{IP})}$ and $\delta_{\mathrm{a}(\mathrm{IVT})}$. The trend of $\delta_{\mathrm{a}(\mathrm{IP})}$ and $\delta_{\mathrm{a}(\mathrm{IVT})}$ was similar to $\delta_{\mathrm{v}}$. In the majority of circumstances, $\delta_{\mathrm{ET}}$ is the largest of those four isotopic parameters, except on 19 May, 4 June and 9 June. About $76 \%$ of $k$ values were negative, and most positive $k$ values occurred at nighttime $(60 \%)$. The percentage of positive $k$ values were $33 \%, 34 \%, 24 \%, 34 \%$ and $10 \%$ in May, June, July, August and September, respectively. The standard deviation (SD) was used here to evaluate the constancy among isotopic parameters at a daily scale. The SD of $\delta_{\mathrm{ET}}, \delta_{\mathrm{v}}, \delta_{\mathrm{a}(\mathrm{IP})}$ and $\delta_{\mathrm{a}(\mathrm{IVT})}$ was $6.08 \%, 0.91 \%, 1.38 \%$ and $0.59 \%$, respectively. Therefore, the constancy of $\delta_{\mathrm{a}}$ was similar to the constancy of $\delta_{\mathrm{v}}$ at a daily scale.

\subsection{Daily variations of HYSPLIT backward trajectories and $\delta_{\mathrm{a}}$ using two methods}

The $500 \mathrm{~m}$ height water vapor backward trajectories revealed that water vapor was from outside the study regions for $10 \mathrm{~d}$ (Fig. 3a), and water vapor was from local ET for $8 \mathrm{~d}$ (Fig. 3b).

As for the IP method, $53.7 \%$ of $\delta_{\mathrm{a}(\mathrm{IP})}$ values met the criteria, and $49.4 \%$ of $\delta_{\mathrm{a}(\mathrm{IP})}$ values meeting the criteria were during the daytime (07:00-19:00). The range of $\delta_{\mathrm{a} \text { (IP) }}$ values meeting the criteria were between $-16.79 \%$ and $-12.95 \%$ o for the $10 \mathrm{~d}$ with external origins (Fig. 3a). The range of $\delta_{\mathrm{a}(\mathrm{IP})}$ values meeting the criteria were between $-12.77 \%$ o and $-9.51 \%$ of the $8 \mathrm{~d}$ with local origins (Fig. 3b).

As for the IVT method, only $4.4 \%$ of $\delta_{\mathrm{a}}$ values met the criteria, and $35.9 \%$ of $\delta_{\mathrm{a}}$ values meeting the criteria were during the daytime (07:00-19:00). The range of $\delta_{\text {a(IVT) }}$ values meeting the criteria were between $-16.31 \%$ and $-13.93 \%$ o for the $10 \mathrm{~d}$ with external origins (Fig. 3a). The range of $\delta_{\mathrm{a}(\mathrm{IVT})}$ values meeting the criteria were between $-12.67 \%$ o and $-9.12 \%$ of the $8 \mathrm{~d}$ with local origins (Fig. $3 b$ ). 


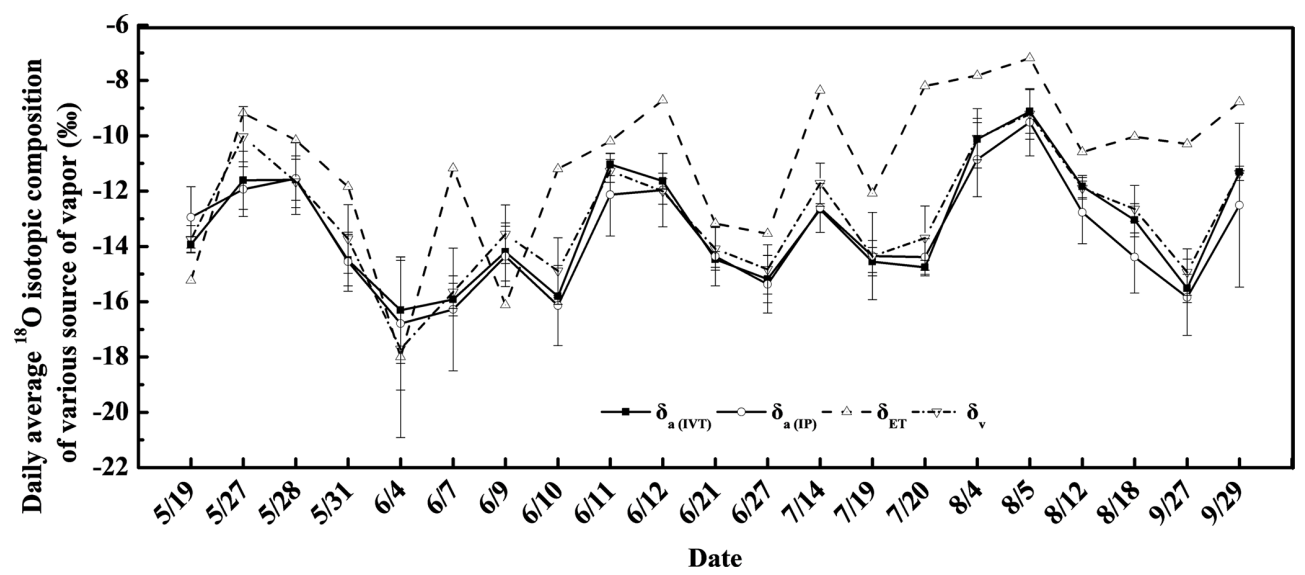

Figure 2. The daily average values of the isotope composition of evapotranspiration vapor $\left(\delta_{\mathrm{ET}}\right)$, the isotope composition of atmospheric vapor $\left(\delta_{\mathrm{V}}\right)$, the estimated isotope composition of ambient vapor using the intersection point method ( $\left.\delta_{\mathrm{a}(\mathrm{IP})}\right)$ and the intermediate value theorem method $\left(\delta_{\mathrm{a}(\mathrm{IVT})}\right)$ in the $21 \mathrm{~d}$ time frame (see the method in Sect. 2.3). Please note that the date format in this figure is month/day.
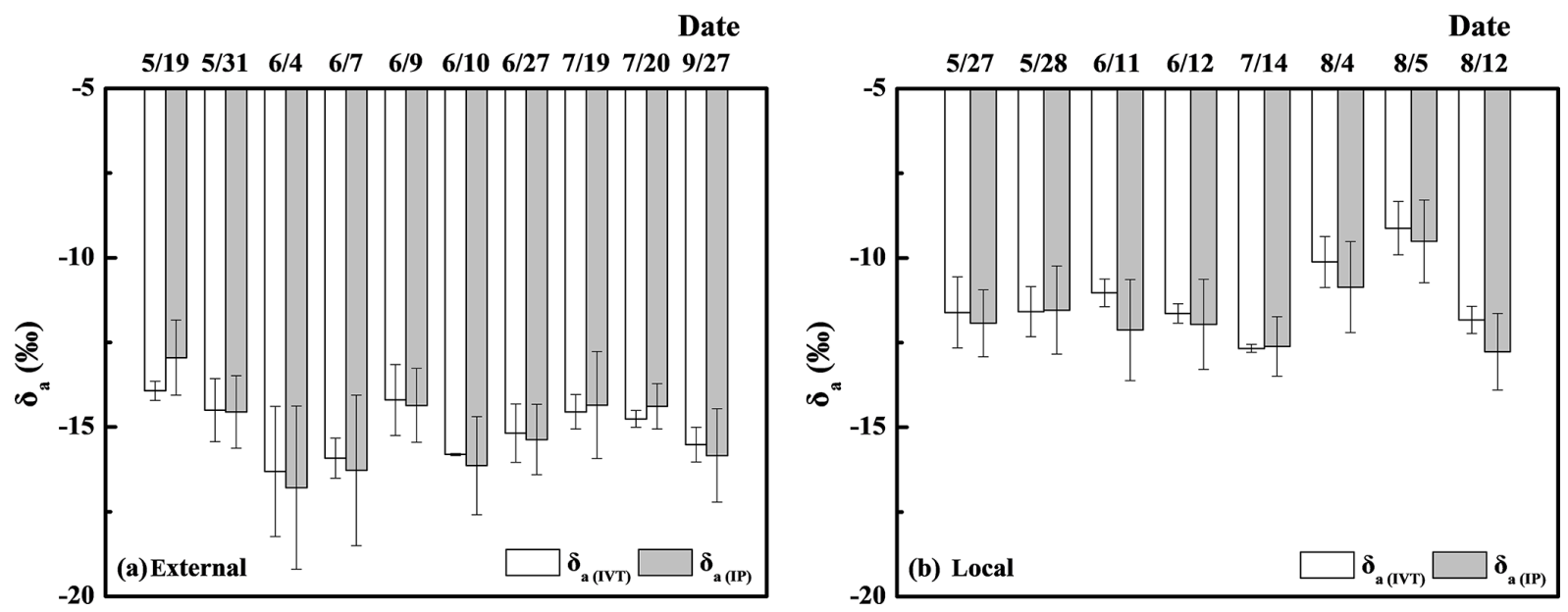

Figure 3. The daily average values of the estimated isotope composition of ambient vapor using the intersection point method $\left(\delta_{\mathrm{a}(\mathrm{IP})}\right)$ and the intermediate value theorem method $\left(\delta_{\mathrm{a}(\mathrm{IVT})}\right)$ after filtering. The Hybrid Single Particle Lagrangian Integrated Trajectory (HYSPLIT) backward trajectory showed both external (a) and local origins (b), respectively. Please note that the date format in this figure is month/day.

\subsection{Linear regression between $\delta_{\mathrm{a}(\mathrm{IP})}$ and $\delta_{\mathrm{a}(\mathrm{IVT})}$}

A method comparison was performed at both a daily scale (Fig. 4a) and point-to-point scale (Fig. 4b). The $21 \mathrm{~d}$ time frame (see the method in Sect. 2.3) in Fig. 3a and b was selected to figure out the daily-scale relationship between $\delta_{\mathrm{a}(\mathrm{IP})}$ and $\delta_{\mathrm{a}(\mathrm{IVT})}$. Point-to-point scale data were based on the 88 points of overlapped $\delta_{\mathrm{a}(\mathrm{IP})}$ and $\delta_{\mathrm{a} \text { (IVT) }}$ (see the method in Sect. 2.3) among all $49 \mathrm{~d}$, which accounted for $7.0 \%$ of $\delta_{\mathrm{a}}$ values using the IP method and $85.4 \%$ of $\delta_{\mathrm{a}}$ values using the IVT method. A linear regression between $\delta_{\mathrm{a}(\mathrm{IP})}$ and $\delta_{\mathrm{a}(\mathrm{IVT})}$ was significant at both a daily scale and point-to-point scale. The degree of agreement was less for the daily timescale than a point-to-point scale, and the RMSE between these two methods at a daily scale and point-to-point scale was $0.618 \%$ and $0.167 \%$, respectively.

\section{Discussion}

\subsection{The reliability of $\delta_{\mathrm{a}}$ estimating methods}

The IP method was based on the assumption that the ambient sources were the same between two continuous observation moments. This is a reasonable assumption for short time intervals. For the IVT method, $\delta_{\mathrm{a}}$ was derived from $\delta_{\mathrm{v}}$ in two continuous moments when their Keeling plot slopes were opposite. The opposite slopes of the Keeling plots were the only requirement. As $\delta_{\mathrm{v}}$ was almost constant in two continuously moments, $\delta_{\text {a(IVT) }}$ was able to be constrained into a small range. The derivation was supported by the intermediate value theorem. Therefore, both methods of estimating $\delta_{\mathrm{a}}$ were theoretically sound. 

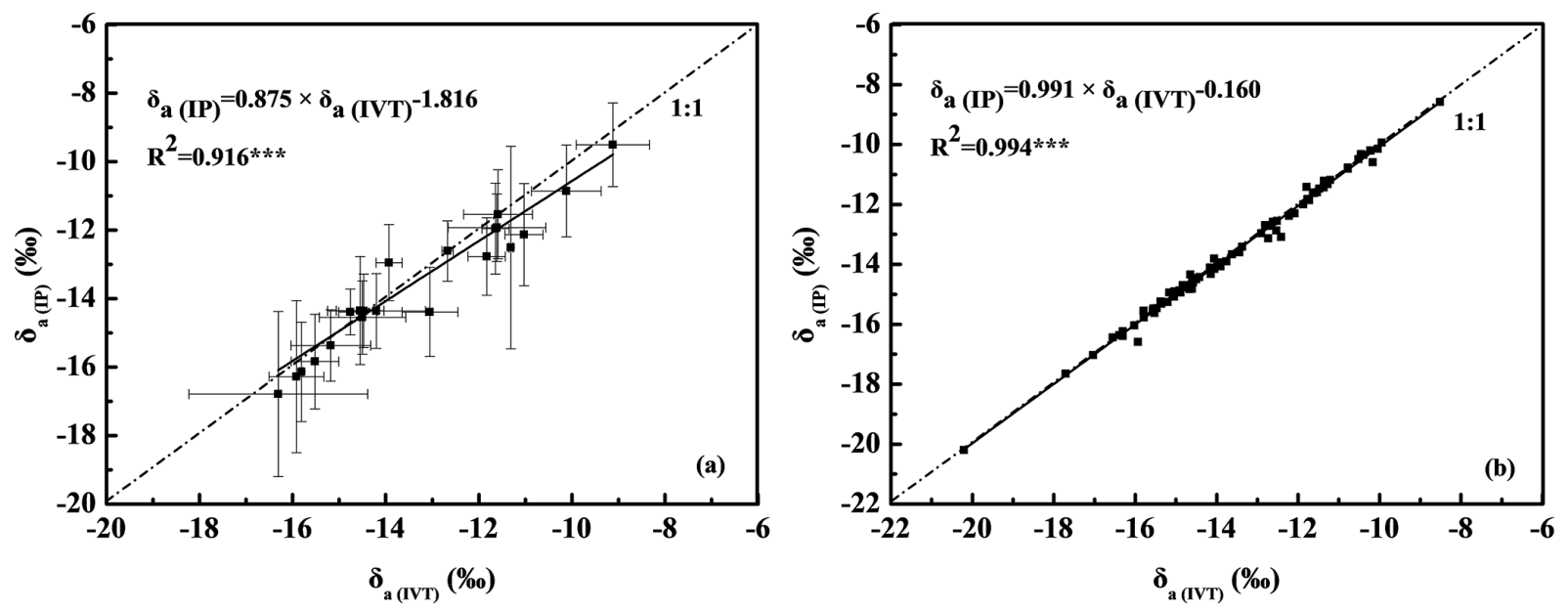

Figure 4. Linear regression between the estimated isotope composition of ambient vapor using the intersection point method $\left(\delta_{\mathrm{a}(\mathrm{IP})}\right)$ and the intermediate value theorem method $\left(\delta_{\mathrm{a}(\mathrm{IVT})}\right)$ on a daily scale (a) and point-to-point scale (b), respectively.

The $\delta_{\mathrm{a}}$ results were also examined by HYSPLIT backward trajectories to identify the different sources of water vapor, which assesses the reliability of both methods indirectly. Based on the trajectory analysis, water vapor in the study area came from westerlies, the northern polar region and local recirculation. Water vapor from southwestern monsoons and the northwestern Pacific were not detected in this study. Based on the isotope variation of meteoric water (Fricke et al., 1999), water vapor from westerlies and the northern polar region was more ${ }^{18} \mathrm{O}$ depleted than local recycled moisture through ET. It was also reported that the water vapor from outside the study regions will lower $\delta_{\mathrm{v}}$ values (Ma et al., 2014; Chen et al., 2015). The calculated $\delta_{\mathrm{a}}$ values of the $10 \mathrm{~d}$ with external sources (Fig. 3a) based on the IP method and IVT approach were lower than those of $8 \mathrm{~d}$ with local origins (Fig. 3b), which was consistent with our expectation. The results indicate that quantifying $\delta_{\mathrm{a}}$ using both the IP method and IVT approach was reliable. The reliability of two methods at a point-to-point scale was also supported by the close relationship of $\delta_{\mathrm{a}}$ using these two independent methods. A daily-timescale result is less reliable than a point-to-point scale.

\subsection{The application of $\delta_{\mathrm{a}}$ for moisture recycling}

When $\delta_{\mathrm{a}}$ was estimated, moisture recycling (e.g., $f_{\mathrm{ET}}$, the contribution of ET fluxes to the total water vapor) can be estimated using the following equations with known $\delta_{\mathrm{a}}, \delta_{\mathrm{ET}}$, $\delta_{\mathrm{v}}, C_{\mathrm{ET}}$ and $C_{\mathrm{v}}$ :

$$
\begin{aligned}
C_{\mathrm{ET}} & =C_{\mathrm{v}} \frac{\delta_{\mathrm{a}}-\delta_{\mathrm{v}}}{\delta_{\mathrm{a}}-\delta_{\mathrm{ET}}}, \\
f_{\mathrm{ET}} & =\frac{C_{\mathrm{ET}}}{C_{\mathrm{v}}} .
\end{aligned}
$$

According to Eqs. (8) and (9), $f_{\mathrm{ET}}$ was only related to $\delta_{\mathrm{a}}, \delta_{\mathrm{v}}$ and $\delta_{\mathrm{ET}}$. These three parameters were obtained for relatively small temporal and spatial scales in this study, making it possible to estimate $f_{\mathrm{ET}}$ at a tower scale. The $f_{\mathrm{ET}}$ estimate will provide a baseline value for rainfall recycling ratio calculations. Previous studies quantified the contribution of recycled vapor to annual or monthly precipitation in river basins using a two-element mixture model (Kong et al., 2013) and three-element mixture (Peng et al., 2011). At the watershed scale, the recycled vapor rate refers to the contributions of moisture from terrestrial ET to annual or monthly precipitation (Trenberth, 1999). It is a key part of local water cycle and the atmospheric water vapor balance (Seneviratne et al., 2006; Aemisegger et al., 2014). In our study, the role of $f_{\mathrm{ET}}$ to regional vapor is similar to the role of recycled vapor rate to annual or monthly precipitation, but $f_{\mathrm{ET}}$ was calculated with fine temporal (e.g., hourly) and spatial (i.e., field scale) scales. At the watershed scale, an assumption was made that there was no isotopic fractionation between transpiration and the source water (Flanagan et al., 1991); advected vapor was assumed to be the precipitation vapor of the upwind station (Peng et al., 2011). However, the isotope composition of plant-transpired vapor is variable within a day, especially under non-steady-state conditions (Farquhar and Cernusak, 2005; Lai et al., 2008; Song et al., 2011). In addition, sometimes it is difficult to select an upwind station without precipitation events. In this study, a field site was selected to calculate the proportion of ET fluxes to total atmospheric vapor, and $f_{\mathrm{ET}}$ was only related to $\delta_{\mathrm{a}}, \delta_{\mathrm{v}}$ and $\delta_{\mathrm{ET}}$ according to Eqs. (8) and (9). This indicates that $f_{\mathrm{ET}}$ calculations are possible for fine temporal and spatial scales after estimating $\delta_{\mathrm{a}}$ using the methods we proposed.

We assumed that the parameter $\delta_{\mathrm{v}}$ in Eq. (8) is the average $\delta_{\mathrm{v}}$ value measured from all the eight heights. $f_{\mathrm{ET}}$ in this study was $23.3 \%$ and $12.7 \%$ from May to September 2017 based on daily $\delta_{\mathrm{a}(\mathrm{IP})}$ and daily $\delta_{\mathrm{a}(\mathrm{IVT})}$, respectively. It was reported that the recycled vapor rate in all of the Shiyang River basin, 


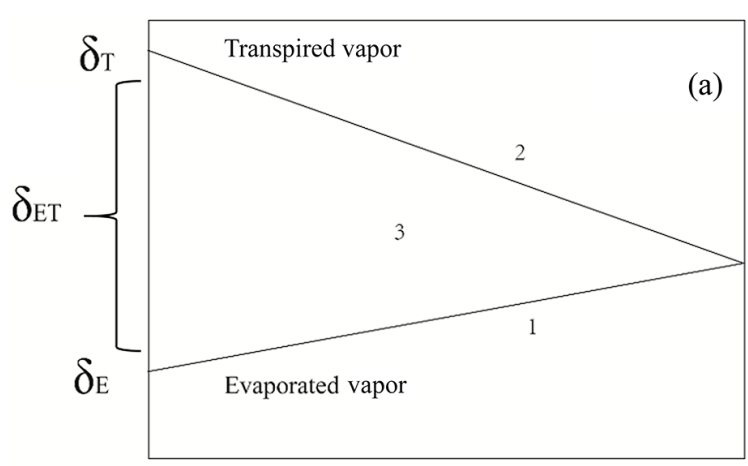

Inverse of $\mathrm{C}_{V}$

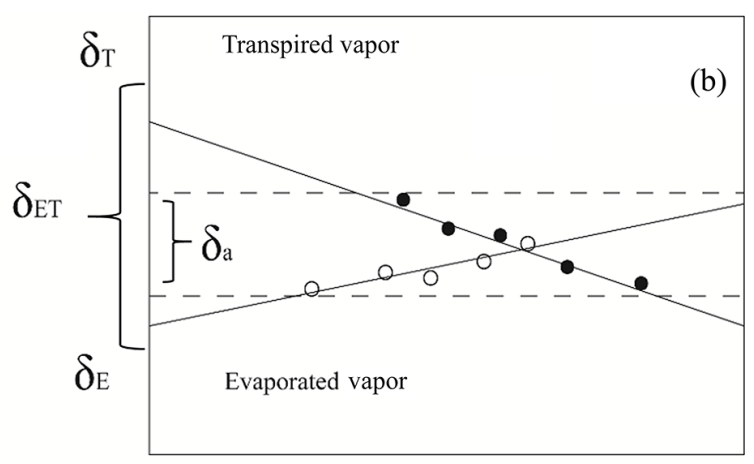

Inverse of $\mathrm{C}_{\mathrm{v}}$

Figure 5. Hypothetical graph of the idealized Keeling plots of the isotope composition of evaporation vapor $\left(\delta_{\mathrm{E}}\right)($ line 1$)$, the isotope composition of transpiration vapor $\left(\delta_{\mathrm{T}}\right)$ (line 2) and the isotope composition of evapotranspiration vapor $\left(\delta_{\mathrm{ET}}\right)$ (area 3) (a). Hypothetical graph of idealized $\delta_{\mathrm{E}}$ and $\delta_{\mathrm{T}}$ lines and the interval of the possible isotope composition of ambient vapor $\left(\delta_{\mathrm{a}}\right)$ in the Keeling plots $(\mathbf{b})$.

oasis region, mountain region and desert region were $23 \%$, $28 \%, 17 \%$ and $15 \%$, respectively $(\mathrm{Li}$, et al., 2016; Zhu, et al., 2019). The $f_{\mathrm{ET}}$ based on daily $\delta_{\mathrm{a}(\mathrm{IP})}$ in our study was close to these earlier studies. The deviation of $f_{\mathrm{ET}}$ based on daily $\delta_{\text {a(IVT) }}$ from previous studies may be because $64.1 \%$ of point-to-point $\delta_{\mathrm{a}(\mathrm{IVT})}$ was observed at nighttime. Normally, nighttime ET is lower than that of the daytime. $f_{\mathrm{ET}}$ may be underestimated using daily $\delta_{\mathrm{a}(\mathrm{IVT})}$. It could also be inferred that $f_{\mathrm{ET}}$ estimation using Eq. (9) may be more reliable using daily $\delta_{\mathrm{a}(\mathrm{IP})}$ than daily $\delta_{\mathrm{a}(\mathrm{IVT})}$.

\subsection{Implications of $\delta_{\mathrm{a}}$}

The concept of $\delta_{\mathrm{E}}$ and $\delta_{\mathrm{T}}$ and their relationships with $\delta_{\mathrm{ET}}$ were first introduced by a hypothetical graph shown in Fig. 5a (Moreira et al., 1997). Line 1 and line 2 were idealized Keeling plots with pure $T$ and pure $E$. The area 3 between line 1 and line 2 represents all the possible Keeling plots with mixed $T$ and $E$. The IVT method in this study provided a general explanation of this figure. As $T$ is a major component of ET in the daytime in a non-arid region (Wang et al., 2014), the slope is generally negative. When $E$ dominates ET in an ecosystem, such as in the nighttime in a nonarid region or in an arid region, the slope should be positive. Mathematically, a negative slope is due to $\delta_{\mathrm{ET}}>\delta_{\mathrm{a}}$, and a positive slope is due to $\delta_{\mathrm{ET}}<\delta_{\mathrm{a}}$. It also reflected that the IVT method could only be used in non-arid ecosystems to ensure the occurrence of a sign switch (e.g., from negative to positive) in Keeling plot slopes. On the contrary, the IP method may not be restricted by the type of ecosystems. Yamanaka and Shimizu (2007) used the assumption that $\delta_{\mathrm{a}}$ of an area of $219.9 \mathrm{~km}^{2}$ was represented by the intersection point of two Keeling plot lines in different sites with synchronous measurements, and they used the intersection value as an approximate value of $\delta_{\mathrm{a}}$. This study was conducted in a maize field using $30 \mathrm{~min}$ interval measurements. The results verified Yamanaka and Shimizu's (2007) assumption in such a fine spa- tial and temporal scale and indicate that accurate $\delta_{\mathrm{a}(\mathrm{IP})}$ could be estimated from the intersection of two Keeling plots regardless of whether the slope is positive or negative, while the $\delta_{\mathrm{a}(\mathrm{IVT})}$ should be restricted in the area between two dotted lines as shown in Fig. 5b (i.e., between the minimum value of $\delta_{\mathrm{v}}$ in a positive slope and the maximum value of $\delta_{\mathrm{v}}$ in a negative slope). Although the IVT method relies on a more stringent precondition for data filtering, this method requires a very simple expression, which only needs two parameters to be measured according to Eq. (7).

While this study is about water vapor ${ }^{18} \mathrm{O}$, the "Keeling plot" was first used by Keeling $(1958,1961)$ to interpret carbon isotope ratios of mixed $\mathrm{CO}_{2}$ and to identify the sources that contribute to increases in atmospheric $\mathrm{CO}_{2}$ concentrations on a regional basis. Compared with $\mathrm{ET}$ in water vapor, which consists of $E$ and $T$, net ecosystem $\mathrm{CO}_{2}$ exchange is comprised of soil respiration $(R)$ and gross primary productivity (GPP). As a ${ }^{13} \mathrm{CO}_{2}$ isotopic Keeling plot reveals a positive slope during both daytime and nighttime (Yakir and Wang, 1996; Unger et al., 2010), the IVT method may not be able to estimate ambient ${ }^{13} \mathrm{CO}_{2}$ isotopic composition $\left(\delta_{\mathrm{a}}{ }^{13} \mathrm{C}\right)$, since there are no opposite slopes in a day. In such a case, the IP method may be implemented in two continuous moments to estimate $\delta_{\mathrm{a}}{ }^{13} \mathrm{C}$ and may consequently further calculate the contribution of net ecosystem exchange (NEE) to atmospheric $\mathrm{CO}_{2}$.

\section{Conclusions}

In this study, we established two methods to quantify $\delta_{\mathrm{a}}$ using the intersection point method and the intermediate value theorem method. The IVT method was used under the condition of opposite slopes of Keeling plots in two continuous moments. The results of estimated $\delta_{\mathrm{a}(\mathrm{IP})}$ and $\delta_{\mathrm{a}(\mathrm{IVT})}$ were consistent with the expectation regardless of whether it was of a local or external origin using an investigation of external 
vapor tracking by the HYSPLIT model. The linear regression between $\delta_{\mathrm{a}(\mathrm{IP})}$ and $\delta_{\mathrm{a}(\mathrm{IVT})}$ was highly significant at both a daily timescale and point-to-point scale.

This study provided insights into the underexplored traditional Keeling plots and provided two methods to estimate $\delta_{\mathrm{a}}$ using the same instrumental setup for the traditional Keeling plot investigations. The estimated $\delta_{\mathrm{a}}$ will make it possible to calculate the ET contribution to regional vapor at a $30 \mathrm{~min}$ interval at a field scale. The results also indicate that using similar framework, $\delta_{\mathrm{a}}{ }^{13} \mathrm{C}$ may also be solvable by the IP method.

Code and data availability. Code and data are available on request.

Supplement. The supplement related to this article is available online at: https://doi.org/10.5194/hess-24-4491-2020-supplement.

Author contributions. YY, TD and LW conceptualized the main research questions. YY collected data and performed the data analyses. YY and LW wrote the first draft of the paper. HW contributed to additional data analyses. All the authors contributed ideas and edited the paper.

Competing interests. The authors declare that they have no conflict of interest.

Special issue statement. This article is part of the special issue "Water, isotope and solute fluxes in the soil-plant-atmosphere interface: investigations from the canopy to the root zone". It is not associated with a conference.

Acknowledgements. We thank Qianning Liu from Jiangxi University of Finance and Economics and Zhengxiang Chen from Capital Normal University for checking the validity of the intermediate value theorem method.

Financial support. This research has been supported by the National Natural Science Foundation of China (grant nos. 51725904, 51621061 and 51861125103), the Discipline Innovative Engineering Plan (111 Program; grant no. B14002), the Graduate International Training and Promotion Program of China Agricultural University (grant no. 31051521), the National Key Research Program (grant no. 2016YFC0400207), the President's International Research Awards from Indiana University, and the Division of Earth Sciences of National Science Foundation (EAR-1554894).

Review statement. This paper was edited by Natalie Orlowski and reviewed by Xin Song and two anonymous referees.

\section{References}

Aemisegger, F., Pfahl, S., Sodemann, H., Lehner, I., Seneviratne, S. I., and Wernli, H.: Deuterium excess as a proxy for continental moisture recycling and plant transpiration, Atmos. Chem. Phys., 14, 4029-4054, https://doi.org/10.5194/acp-144029-2014, 2014.

Brunel, J. P., Walker, G. R., Dighton, J. C., and Monteny, B.: Use of stable isotopes of water to determine the origin of water used by the vegetation and to partition evapotranspiration. A case study from HAPEX-Sahel, J. Hydrol., 188-189, 466-481, https://doi.org/10.1016/s0022-1694(96)03188-5, 1997.

Chen, F. L., Zhang, M. J., Ma, Q., Wang, S. J., Li, X. F., and Zhu, X. F.: Stable isotopic characteristics of precipitation in Lanzhou city and its surrounding areas, Northwest China, Environ. Earth Sci., 73, 4671-4680, https://doi.org/10.1007/s12665-014-37766, 2015.

Corneo, P. E., Kertesz, M. A., Bakhshandeh, S., Tahaei, H., Barbour, M. M., and Dijkstra, F. A.: Studying root water uptake of wheat genotypes in different soils using water $\delta^{18} \mathrm{O}$ stable isotopes, Agr. Ecosyst. Environ., 264, 119-129, https://doi.org/10.1016/j.agee.2018.05.007, 2018.

Craig, H. and Gordon, L. I.: Deuterium and oxygen 18 variations in the ocean and marine atmosphere, in: Stable Isotopes in Oceanographic Studies and Paleotemperatures, edited by: Tongiorgi, E., Consiglio nazionale delle richerche laboratorio di geologia nuclear, p. 9, 1965

Cui, J., Tian, L., Wei, Z., Huntingford, C., Wang, P., Cai, Z., Ma, N., and Wang, L.: Quantifying the controls on evapotranspiration partitioning in the highest alpine meadow ecosystems, Water Resour. Res., 56, e2019WR024815, https://doi.org/10.1029/2019WR024815, 2020.

Draxler, R. R.: Evaluation of an ensemble dispersion calculation, J. Appl. Meteorol., 42, 308-317, https://doi.org/10.1175/15200450(2003)042<0308:EOAEDC>2.0.CO;2, 2003.

Draxler, R. R. and Hess, G.: Description of the HYSPLIT4 modeling system, NOAA Tech Memo ERL ARL-224, Dec, Air Resources Laboratory, 24 p., 1997.

Farquhar, G. D. and Cernusak, L. A.: On the isotopic composition of leaf water in the non-steady state, Funct. Plant Biol., 32, 293 303, https://doi.org/10.1071/FP04232, 2005.

Fiorella, R. P., Poulsen, C. J., and Matheny, A. M.: Seasonal patterns of water cycling in a deep, continental mountain valley inferred from stable water vapor isotopes, J. Geophys. Res.-Atmos., 123, 7271-7291, https://doi.org/10.1029/2017JD028093, 2018.

Flanagan, L. B., Comstock, J. P., and Ehleringer, J. R.: Comparison of modeled and observed environmental influences on the stable oxygen and hydrogen isotope composition of leaf water in Phaseolus vulgaris L., Plant Physiol., 96, 588-596, https://doi.org/10.1104/pp.96.2.588, 1991.

Fricke, H. C., O'Neil, J. R. J. E., and Letters, P. S.: The correlation between ${ }^{18} \mathrm{O} /{ }^{16} \mathrm{O}$ ratios of meteoric water and surface temperature: its use in investigating terrestrial climate change over geologic time, Earth Planet. Sci. Lett., 170, 181-196, https://doi.org/10.1016/S0012-821X(99)00105-3, 1999.

Galewsky, J., Rella, C., Sharp, Z., Samuels, K., and Ward, D.: Surface measurements of upper tropospheric water vapor isotopic composition on the Chajnantor Plateau, Chile, Geophys. Res. Lett., 38, 1-5, https://doi.org/10.1029/2011GL048557, 2011. 
Good, S. P., Soderberg, K., Wang, L., and Caylor, K. K.: Uncertainties in the assessment of the isotopic composition of surface fluxes: A direct comparison of techniques using laser-based water vapor isotope analyzers, J. Geophys. Res.-Atmos., 117, D15301, https://doi.org/10.1029/2011JD017168, 2012.

Griffis, T. J., Wood, J. D., Baker, J. M., Lee, X., Xiao, K., Chen, Z., Welp, L. R., Schultz, N. M., Gorski, G., Chen, M., and Nieber, J.: Investigating the source, transport, and isotope composition of water vapor in the planetary boundary layer, Atmos. Chem. Phys., 16, 5139-5157, https://doi.org/10.5194/acp16-5139-2016, 2016.

Hobbins, M. T., Ramirez, J. A., and Brown, T. C.: The complementary relationship in estimation of regional evapotranspiration: An enhanced advection-aridity model, Water Resour. Res., 37, 1389-1403, https://doi.org/10.1029/2000WR900359, 2001.

Jung, M., Reichstein, M., Ciais, P., Seneviratne, S. I., Sheffield, J., Goulden, M. L., Bonan, G., Cescatti, A., Chen, J., and De Jeu, R.: Recent decline in the global land evapotranspiration trend due to limited moisture supply, Nature, 467, 951-954, https://doi.org/10.1038/nature09396, 2010.

Kaseke, K. F., Wang, L., Wanke, H., Tian, C., Lanning, M., and Jiao, W.: Precipitation origins and key drivers of precipitation isotope $\left({ }^{18} \mathrm{O},{ }^{2} \mathrm{H}\right.$, and $\left.{ }^{17} \mathrm{O}\right)$ compositions over windhoek, J. Geophys. Res.-Atmos., 123, 7311-7330, https://doi.org/10.1029/2018JD028470, 2018.

Keeling, C. D.: The concentration and isotopic abundances of atmospheric carbon dioxide in rural areas, Geochim. Cosmochim. Ac., 13, 322-334, https://doi.org/10.1016/0016-7037(58)900334, 1958 .

Keeling, C. D.: The concentration and isotopic abundances of carbon dioxide in rural and marine air, Geochim. Cosmochim. Ac., 24, 277-298, https://doi.org/10.1016/0016-7037(61)90023$0,1961$.

Keppler, F., Schiller, A., Ehehalt, R., Greule, M., Hartmann, J., and Polag, D.: Stable isotope and high precision concentration measurements confirm that all humans produce and exhale methane, J. Breath Res., 10, 016003, https://doi.org/10.1088/17527155/10/1/016003, 2016.

Kerstel, E. and Gianfrani, L.: Advances in laser-based isotope ratio measurements: selected applications, Appl. Phys. B, 92, 439449, https://doi.org/10.1007/s00340-008-3128-x, 2008.

Kong, Y., Pang, Z., and Froehlich, K.: Quantifying recycled moisture fraction in precipitation of an arid region using deuterium excess, Tellus B, 65, 19251, https://doi.org/10.3402/tellusb.v65i0.19251, 2013.

Lai, C.T., Ometto, J. P., Berry, J. A., Martinelli, L. A., Domingues, T. F., and Ehleringer, J. R.: Life form-specific variations in leaf water oxygen-18 enrichment in Amazonian vegetation, Oecologia, 157, 197-210, https://doi.org/10.1007/s00442-008-1071-5, 2008.

Lanning, M., Wang, L., Benson, M., Zhang, Q., and Novick, K. A.: Canopy isotopic investigation reveals different water uptake dynamics of maples and oaks, Phytochemistry, 175, 112389, https://doi.org/10.1016/j.phytochem.2020.112389, 2020.

Li, Z., Feng, Q., Wang, Q., Kong, Y., Chen, A., Song, Y., Li, Y., Li, J., and Guo, X.: Contributions of local terrestrial evaporation and transpiration to precipitation using $\delta^{18} \mathrm{O}$ and D-excess as a proxy in Shiyang inland river basin in China, Global Planet. Change,
146, 140-151, https://doi.org/10.1016/j.gloplacha.2016.10.003, 2016.

Lovie, P.: Coefficient of variation, in: Encyclopedia of Statistics in Behavioral Science, Wiley, https://doi.org/10.1002/0470013192.bsa107, 2005.

Ma, Q., Zhang, M., Wang, S., Wang, Q., Liu, W., Li, F., and Chen, F.: An investigation of moisture sources and secondary evaporation in Lanzhou, Northwest China, Environ. Earth Sci., 71, 33753385, https://doi.org/10.1007/s12665-013-2728-x, 2014.

Mahindawansha, A., Orlowski, N., Kraft, P., Rothfuss, Y., Racela, H., and Breuer, L.: Quantification of plant water uptake by water stable isotopes in rice paddy systems, Plant Soil, 429, 281-302, https://doi.org/10.1007/s11104-018-3693-7, 2018.

Majoube, M.: Fractionnement en oxygene 18 et en deuterium entre l'eau et sa vapeur, J. Chi. Phys., 68, 1423-1436, https://doi.org/10.1051/jcp/1971681423, 1971.

Merlivat, L. and Jouzel, J.: Global climatic interpretation of the deuterium-oxygen 18 relationship for precipitation, J. Geophys. Res.-Oceans, 84, 5029-5033, https://doi.org/10.1029/JC084iC08p05029, 1979.

Miller, J. B. and Tans, P. P.: Calculating isotopic fractionation from atmospheric measurements at various scales, Tellus B, 55, 207214, https://doi.org/10.1034/j.1600-0889.2003.00020.x, 2003.

Moreira, M., Sternberg, L., Martinelli, L., Victoria, R., Barbosa, E., Bonates, L., and Nepstad, D.: Contribution of transpiration to forest ambient vapour based on isotopic measurements, Glob. Change Biol., 3, 439-450, https://doi.org/10.1046/j.13652486.1997.00082.x, 1997.

Parkes, S. D., McCabe, M. F., Griffiths, A. D., Wang, L., Chambers, S., Ershadi, A., Williams, A. G., Strauss, J., and Element, A.: Response of water vapour D-excess to land-atmosphere interactions in a semi-arid environment, Hydrol. Earth Syst. Sci., 21, 533-548, https://doi.org/10.5194/hess-21-533-2017, 2017.

Peng, T. R., Liu, K. K., Wang, C. H., and Chuang, K. H.: A water isotope approach to assessing moisture recycling in the island-based precipitation of Taiwan: A case study in the western Pacific, Water Resour. Res., 47, W08507, https://doi.org/10.1029/2010WR009890, 2011.

Seneviratne, S. I., Lüthi, D., Litschi, M., and Schär, C.: Landatmosphere coupling and climate change in Europe, Nature, 443 205-209, https://doi.org/10.1038/nature05095, 2006.

Song, X., Barbour, M. M., Saurer, M., and Helliker, B. R.: Examining the large-scale convergence of photosynthesisweighted tree leaf temperatures through stable oxygen isotope analysis of multiple data sets, New Phytol., 192, 912-924, https://doi.org/10.1111/j.1469-8137.2011.03851.x, 2011.

Song, X., Simonin, K. A., Loucos, K. E., and Barbour, M. M.: Modelling non-steady-state isotope enrichment of leaf water in a gasexchange cuvette environment, Plant Cell Environ., 38, 26182628, https://doi.org/10.1111/pce.12571, 2015.

Steen-Larsen, H. C., Johnsen, S. J., Masson-Delmotte, V., Stenni, B., Risi, C., Sodemann, H., Balslev-Clausen, D., Blunier, T., Dahl-Jensen, D., Ellehøj, M. D., Falourd, S., Grindsted, A., Gkinis, V., Jouzel, J., Popp, T., Sheldon, S., Simonsen, S. B., Sjolte, J., Steffensen, J. P., Sperlich, P., Sveinbjörnsdóttir, A. E., Vinther, B. M., and White, J. W. C.: Continuous monitoring of summer surface water vapor isotopic composition above the Greenland Ice Sheet, Atmos. Chem. Phys., 13, 4815-4828, https://doi.org/10.5194/acp-13-4815-2013, 2013. 
Stein, A., Draxler, R. R., Rolph, G. D., Stunder, B. J., Cohen, M., and Ngan, F.: NOAA's HYSPLIT atmospheric transport and dispersion modeling system, B. Am. Meteorol. Soc., 96, 20592077, https://doi.org/10.1175/BAMS-D-14-00110.1, 2015.

Trenberth, K. E.: Atmospheric moisture recycling: Role of advection and local evaporation, J. Climate, 12, 1368-1381, https://doi.org/10.1175/15200442(1999)012<1368:AMRROA>2.0.CO;2, 1999.

Unger, S., Máguas, C., Pereira, J. S., Aires, L. M., David, T. S., and Werner, C.: Disentangling drought-induced variation in ecosystem and soil respiration using stable carbon isotopes, Oecologia, 163, 1043-1057, https://doi.org/10.1007/s00442-010-15766, 2010.

Wagle, P., Skaggs, T. H., Gowda, P. H., Northup, B. K., and Neel, J. P.: Flux variance similarity-based partitioning of evapotranspiration over a rainfed alfalfa field using high frequency eddy covariance data, Agr. Forest Meteorol., 285, 107907, https://doi.org/10.1016/j.agrformet.2020.107907, 2020.

Wang, L., Caylor, K. K., and Dragoni, D.: On the calibration of continuous, high-precision $\delta^{18} \mathrm{O}$ and $\delta^{2} \mathrm{H}$ measurements using an off-axis integrated cavity output spectrometer, Rapid Commun. Mass. Sp., 23, 530-536, https://doi.org/10.1002/rcm.3905, 2009.

Wang, L., Caylor, K. K., Villegas, J. C., Barron-Gafford, G. A., Breshears, D. D., and Huxman, T. E.: Partitioning evapotranspiration across gradients of woody plant cover: Assessment of a stable isotope technique, Geophys. Res. Lett., 37, L09401, https://doi.org/10.1029/2010GL043228, 2010.

Wang, L., Good, S. P., Caylor, K. K., and Cernusak, L. A.: Direct quantification of leaf transpiration isotopic composition, Agr. Forest Meteorol., 154-155, 127-135, https://doi.org/10.1016/j.agrformet.2011.10.018, 2012.

Wang, L., Niu, S., Good, S. P., Soderberg, K., McCabe, M. F., Sherry, R. A., Luo, Y., Zhou, X., Xia, J., and Caylor, K. K.: The effect of warming on grassland evapotranspiration partitioning using laser-based isotope monitoring techniques, Geochim. Cosmochim. Ac., 111, 28-38, https://doi.org/10.1016/j.gca.2012.12.047, 2013.

Wang, L., Good, S. P., and Caylor, K. K.: Global synthesis of vegetation control on evapotranspiration partitioning, Geophys. Res. Lett., 41, 6753-6757, https://doi.org/10.1002/2014GL061439, 2014.

Wei, Z., Yoshimura, K., Okazaki, A., Kim, W., Liu, Z., and Yokoi, M.: Partitioning of evapotranspiration using high-frequency water vapor isotopic measurement over a rice paddy field, Water Resour. Res., 51, 3716-3729, https://doi.org/10.1002/2014WR016737, 2015.
Werner, M., Langebroek, P. M., Carlsen, T., Herold, M., and Lohmann, G.: Stable water isotopes in the ECHAM5 general circulation model: Toward high-resolution isotope modeling on a global scale, J. Geophys. Res.-Atmos., 116, D15109, https://doi.org/10.1029/2011JD015681, 2011.

Yakir, D. and Sternberg, L.: The use of stable isotopes to study ecosystem gas exchange, Oecologia, 123, 297-311, https://doi.org/10.1007/s004420051016, 2000.

Yakir, D. and Wang, X.F.: Fluxes of $\mathrm{CO}_{2}$ and water between terrestrial vegetation and the atmosphere estimated from isotope measurements, Nature, 380, 515-517, https://doi.org/10.1038/380515a0, 1996.

Yamanaka, T. and Shimizu, R.: Spatial distribution of deuterium in atmospheric water vapor: Diagnosing sources and the mixing of atmospheric moisture, Geochim. Cosmochim. Ac., 71, 31623169, https://doi.org/10.1016/j.gca.2007.04.014, 2007.

Yepez, E. A., Williams, D. G., Scott, R. L., and Lin, G.: Partitioning overstory and understory evapotranspiration in a semiarid savanna woodland from the isotopic composition of water vapor, Agr. Forest Meteorol., 119, 53-68, https://doi.org/10.1016/S0168-1923(03)00116-3, 2003.

Zhang, L., Dawes, W., and Walker, G.: Response of mean annual evapotranspiration to vegetation changes at catchment scale, Water Resour. Res., 37, 701-708, https://doi.org/10.1029/2000WR900325, 2001.

Zhang, Y., Shen, Y., Sun, H., and Gates, J. B.: Evapotranspiration and its partitioning in an irrigated winter wheat field: A combined isotopic and micrometeorologic approach, J. Hydrol., 408, 203 211, https://doi.org/10.1016/j.jhydrol.2011.07.036, 2011.

Zhao, L., Liu, X., Wang, N., Kong, Y., Song, Y., He, Z., Liu, Q., and Wang, L.: Contribution of recycled moisture to local precipitation in the inland Heihe River Basin, Agr. Forest Meteorol., 271, 316-335, https://doi.org/10.1016/j.agrformet.2019.03.014, 2019.

Zhu, G., Guo, H., Qin, D., Pan, H., Zhang, Y., Jia, W., and Ma, X.: Contribution of recycled moisture to precipitation in the monsoon marginal zone: Estimate based on stable isotope data, J. Hydrol., 569, 423-435, https://doi.org/10.1016/j.jhydrol.2018.12.014, 2019. 